\title{
A Study on China's Corporate Crime Enforcement: An Emerging Reprieve Approach
}

\author{
TAO Langxiao \\ University of International Business and Economics, Beijing, China
}

\begin{abstract}
China regulates the criminal behaviors of corporations through the "unite crime" provisions of the Criminal Code. The existing laws and theories are not ambiguous, but enforcement methods no longer serve the needs of Chinese society. This has had harmful collateral consequences for public interests, providing limited rights protection for entrepreneurs and having insufficient effects in promoting criminal compliance over the long term. Since 2018, China has been accepting restorative justice to resolve the problems in traditional methods, forming a new reprieve approach in dealing with corporate crimes. Judicial activities have been improved by encouraging bail for entrepreneurs and more property rights protections. Following this trend, there must be further law reforms that can develop China's deferred prosecution agreement system and incentivize corporations to apply criminal compliance programs.
\end{abstract}

Keywords: corporate crime, China, deferred prosecution agreement, criminal compliance

\section{Introduction}

Since the 1990s, corporate crime started to exist as an independent category of "unite crime" in the Chinese Criminal Code. The number of laws and cases has been growing over the past two decades. However, the enforcement of corporate crime has its deficiencies, resulting in serious harm to public interests. While a few works published in English studied have examined Chinese corporate crime, most offer a basic introduction to the Chinese rules without analyzing relevant enforcement activities and cases' social influences (Farrar, 2002; Miles \& Zhang, 2006; Lin, 2015; Zhang, 2012). Additionally, none were published after 2018 when corporate crime enforcement in China initiated a new reprieve approach. This article addresses this academic gap by providing an update account of corporate crime enforcement in China. In its second section, the article offers a comprehensive overview of the development of corporate crime in China. In its third section, it discusses ongoing problems with China's corporate crime law and judicial enforcement activities by critically examining the noted cases and empirical results. In its fourth section, it analyzes recent policy trends and provides further suggestions on how China should improve corporate crime enforcement in the future. The final section concludes.

\section{The Development of Corporate Crime in China}

A corporation is a recognized legal person with independent property and naming and is responsible for

TAO Langxiao, Ph.D. student, Law School, University of International Business and Economics, Beijing, China. 
complying with most laws as a natural person. The development of corporations and relevant laws in China has been very unique due to the country's culture features and economic structure. This section starts with a review of the business culture of ancient China, which still influences the practices of contemporary corporations. The section then introduces the transformation of corporate crime laws and relevant scholarly theories. Finally, it analyzes the different criminal compliance features of different types of corporations.

\section{The History of China's Business Culture and Corporations}

As is well known, Confucian theory has governed Chinese society for more than 2,000 years since feudal times. Under this theory, in serving the social stability of an agricultural civilization, social classes in ancient China were divided into "scholars, farmers, artisans, and merchants" within "merchants" regarded as of the lowest status, strongly discouraging the development of business in China (Kuhn, 1984, pp. 20-21). There were even laws forbidding businessmen and their children from taking part in the imperial examination, meaning that they could not secure an official position in government. Given this background, business in the country developed slowly. By the Song Dynasty (AD 960-AD 1279), there were business associations working in cooperation with governments to grant licenses to individual businessmen and regulate their businesses (Wei, 1997). This marked the start of business unity in China, but nothing close to the state of the modern corporate economy. Only in the late Qing Dynasty (AD 1903), influenced by the Western industrial revolution and corporate culture, was the first Corporate Law created in China, after which corporations started to form in country (Fan \& Li, 2018). However, there was no corporate crime because criminal laws at the time only applied to individuals. A few years later, China entered a near 40-year war against colonization and secession, leaving little room for the development of corporations.

Due to strong suppression to business and serious market control throughout history, many traditional businessmen survived by securing privileges from the government, thus lacking a sense of market fairness and equal competition. How could good relations and privilege be maintained? Most businessmen reached their goals by hosting feasts and presenting gifts to officials in charge. Such "bribery" became a common feature of business in ancient China. As there were not many large and influential business entities at the time, the need to recognize organizations' independent legal personality and regulate them through criminal law was not apparent. As a result, China's traditional business culture lacks notions of compliance. There are still some corporations and entrepreneurs to this day secure business opportunities through their private relations with officials, by hosting feasts and offering expensive gifts, by faking trading records, and through unlawful tax evasion.

After the People's Republic of China was founded, from 1949 to 1992, China adopted its Planned Economy Model under which no modern corporations existed and transactions with the free market and free pricing were criminalized under “Tou Ji Dao Ba（投机倒把罪”” and punishable for three years imprisonment. In 1992, the Chinese socialist market economy was founded, and the Corporate Law was released when corporations started to be regarded as "legal persons" in the following year. In 1997, the Criminal Code was reformed to include "corporate crime" in its "united crime" provision. Since then, corporate crime enforcement has been an important part of judicial activity with growing influence on the economy and on social life.

Since China did not experience an industrial revolution, and the socialist market economy was born suddenly based on the government's policy changes, the regulation of corporations suffered over the first two 
decades. A fast rise of gross domestic product (GDP) came at the expense of loosened market regulations. Even though laws were in place, administrative agencies and judicial authorities lacked resources and effective means to supervise the behaviors of corporations. This further encouraged habits of non-compliance from traditional business culture, resulting in a large number of corporate crimes remaining hidden. It is often said that: "the legislation seems serious, but violations are common, and law enforcement is selective". Currently, with the growth of its socialist market economy, China is searching for more effective ways to regulate corporate crimes.

\section{The Development of Corporate Crime Laws and Theories}

Under Roman rule Societas Delinquere Non Potest, a corporation is not a natural person, cannot form a criminal mind, and thus should not be criminally liable. Even though this rule has been breached by most countries, there is still much debate regarding the identification and punishment of corporate crimes, and the Chinese approach is very unique. Since the recognition of a corporation's legal personality in 1993, Chinese criminal legislation has gradually developed a new understanding of what corporate crime is and how it should be punished.

What is corporate crime? The answer to this question is not clear because there are many different theories in this area and no consensus among countries has yet been reached. The earliest theory is the Vicarious Liability Theory (Diskant, 2008) influencing United States. The theory is based on the doctrine of respondeat superior of tort law. A corporation is considered an employer with the responsibility to supervise its employees' or agents' behaviors and thus may be liable for a crime committed by its employees or agents. Since the U.S. Supreme Court's decision made in New York Central ${ }^{1}$, a corporation may be held criminally liable for the acts or omissions of its employees when a criminal act committed is: (i) within the scope of the employee's employment; and (ii) for the benefit of the corporation. Second, the Identification Theory (Parsons, 2003) is also accepted by many countries, such as the United Kingdom. For crimes requiring a clear means rea, the identification principle theory deems a corporation's "directing mind and will", or the acts and state of mind of high-level directors or managers, at fault. Third, the Corporate Culture Theory (de Maglie, 2005) developed in Australia. When a corporate culture exists within a corporation that directs, encourages, tolerates or leads to non-compliance through offence provision, the corporation is criminally liable for a crime committed by its employees or agents. Many other theories have also been developed by scholars or through famous cases, including the Collective Knowledge Doctrine (Ragozino, 1995).

The application of China's corporate crime laws relies heavily on theoretical interpretations because its direct legislation is vague. Only one provision of the Criminal Code focuses on its identification: "A company, enterprise, institution, organization, or group which commits an act endangering society that is considered a crime under the law shall bear criminal responsibility". ${ }^{2}$ Corporate crime is in turn defined as a unite crime awaiting further interpretation on how to apply it in judicial reality. A so-called "unite crime" is a crime committed by an organization. In 2001, an unofficial interpretation provided in a government document states: "a unite crime has to be committed in the name of a unite and illegal gains must have been given to the unite".

\footnotetext{
${ }^{1}$ New York Central \& Hudson River Railroad Co. v. United States, 212 U.S. 481(1909).

2 Criminal Law of the People's Republic of China, Section 4 Crimes Committed by a Unit, Article 30.

3 Supreme People's Court on the "Minutes of the National Forum on Trial of Financial Crime Cases by National Courts" on 21 January 2001.
} 
However, this approach has been widely critiqued by Chinese scholars. After considerable debate, the theory receiving the most support is as follows: "a unite crime has to be committed for the benefit of a unite and the decision must be made by the unite as a whole or by persons in charge in the unite" (Li, 2013, pp. 153-160). This theory, which is very similar to the Identification Theory, has been widely adopted by Chinese courts in recent years. ${ }^{4}$

What is the appropriate punishment for corporate crime? Three main forms of sensation are used to punish corporations in modern countries. First, a money penalty on criminal corporations, which imposes criminal fines, is the most common type found in nearly every country with corporate crime. Many countries, such as the United States adopt clear standards that determine how judges must value fines appropriate for different corporate criminals. ${ }^{5}$ Second, sanctions on the qualifications of criminal corporations can include the suspension of or rescaling business certification, exclusion from participation in public contracts, placement under judicial supervision for a period of time, and dissolution. For instance, in France, when: (i) a company was created to commit an offence; or (ii) a corporate entity was diverted from its corporate objects to commit a felony or other offence punishable by a prison sentence of three years or more, dissolution is imposed on the company (Orland \& Cachera, 1995). Third, directors or managers in charge of criminal corporations can be punished. In most countries, individuals are rarely held directly liable for corporate crimes simply due to their position in a company. However, China adopts this method as a major form of corporate crime punishment. The Chinese Criminal Code writes:

A unit which commits a crime shall be punished with a fine, and the person(s) directly in charge and other person(s) directly involved in the crime shall be given a punishment. Where Specific Provisions of this Law or other laws stipulate otherwise, such stipulation shall be applied. ${ }^{6}$

This Chinese corporate crime punishment system has been described by scholars as a combination of single-penalty and dial-penalty systems (Ye, 2008). Most crimes apply a dial-penalty whereby a criminal corporation is fined and the persons in charge are fined or otherwise appropriately penalized (e.g., through imprisonment). Such persons usually include legal representatives, directors, and other high-level managers. A few crimes come with the single-penalty, whereby only those in charge are punished and no fine is imposed on the corporation. The single-penalty method is also called the substitute-penalty, as it focuses on punishing individuals with certain responsibilities for an entire corporation.

\section{Types of Corporations and Differences on Criminal Compliance}

Under the Chinese socialist market economy, based on the nature of shareholding, there are three main types of corporations in China: state-, private-, and foreign- owned corporations. These entities greatly differ in their business structures and criminal compliance rules with private-owned corporations usually presenting the most problems.

According to a research report on crimes committed by entrepreneurs in mainland China, 6,988 cases involving 8,965 crimes and 8,412 entrepreneurs occurred from December 2013 to November 2018 (Zhang, 2019).

\footnotetext{
${ }^{4}$ See the No. 89 Criminal Final Judgement of 1(2017) by the Lan Zhou Intermediate People's Court in Gansu Province.

5 See United States Federal Sentencing Guidelines, Chapter 8 Sentencing of Organizations.

${ }^{6}$ Criminal Law of the People's Republic of China, Section 4 Crimes Committed by a unit, Article 31.
} 
When dividing entrepreneurs into state- and private- owned entrepreneurs, the 7,215 private-owned entrepreneurs form the majority (85.77\%) (Zhang, 2019). Another research report discusses unite crimes committed in Hubei Province in 2017, finding 94 cases including 102 unites for that year where 89 private-owned corporations also form the majority (87\%) (Chen, 2018). In 2017, private-owned corporations represented $79.4 \%$ of corporations in China (Chen, 2018). From these data, it can be inferred that criminal problems facing private-owned corporations are the most serious due to their prevalence of corporate and individual crimes related to corporate behaviors.

The conclusions of previous research are consistent with the view that private-owned corporations are the generally lowest in criminal compliance. In state-owned corporations, major directors and chief managers are appointed by the government under a strict selection process based on candidates' education backgrounds, personalities, previous experiences, and other related factors. The persons appointed are generally of high social standing with the potential to run corporations with integrity. In terms of business structures, a state-owned corporation must employ a party committee representing the Chinese Communist Party to supervise daily business and compliance work. Since 2018, the Chinese government has published many documents that encourage these corporations to build corporate compliance programs. ${ }^{7}$ Due to such efforts, state-owned corporations are seldom involved in criminal cases. Foreign-owned corporations are also strong in criminal compliance because they usually adopt systematic compliance programs developed for long-term management overseas. However, private-owned corporations and especially those of medium and small sizes and developing in rural areas usually adopt loose management systems without paying compliance costs. A study on 300 corporations in China shows that only $35 \%$ of private-owned corporations have compliance policies while only $19 \%$ have created employee manuals on criminal matters, such as preventing commercial bribery. ${ }^{8}$ As a result, plans to prevent corporate crime in China should focus on improving criminal compliance in private-owned corporations.

\section{Ongoing Problems With China's Corporate Crime Enforcement}

There is currently no special procedure for managing corporate crime in China. When a corporation is suspected of committing a crime, it is usually investigated by police, prosecuted by a prosecutor, and tried by a judge, as is done for a natural person suspect. Nearly all relevant directors are arrested and detained. However, this traditional form of enforcement can no longer work in China due to its collateral consequences for public interests, lacking protection of rights in proceedings, and failure to encourage corporate compliance in the future. This section illustrates these problems by analyzing three Chinese cases.

\section{Collateral Consequences: The Qvodplayer Case}

Corporate crime enforcement has always been a challenge because sentencing a corporation may have considerable collateral consequences for the public interest. The 2005 Arthur Andersen Case in the United States shows that a criminal sentence may bankrupt a large corporation and result in massive unemployment, potentially

\footnotetext{
${ }^{7}$ See Chinese State-Owned Assets Supervision and Administration issued the compliance management for central state-owned enterprises (for trial implementation); the Chinese National Development and Reform Commission and other seven departments jointly issued the Guidelines for the Compliance Management of Enterprises Overseas Operations.

${ }^{8}$ See Fang Da Law Firm Compliance Team, 2017-2018 the Bluebook on China's Annual Compliance, published online by Fang Da Law Firm, p. 135.
} 
influencing an entire industry or a nation's economy (Oded, 2011). Similar cases are observed in China. We take the Qvodplayer case as an example.

Shenzhen Qvod Technology Co. Ltd., a private-owned corporation, was registered in China in 2007, and developed the popular Qvodplayer video player with 300 million users in 2012, when the total number of web users in China is merely 538 million. The company generated more than 350 million yuan profits each year, invented several patented technologies, and provided many job opportunities in the Internet industry. However, in 2014, the Qvod Corporation and its chief directors were investigated and prosecuted for disseminating pornographic videos for profit, as they did not prevent users from sending such videos through the Qvodplayer. In 2016, the corporation and its directors were found guilty. The corporation was charged 10 million yuan in fines and its directors were sentenced to more than three years imprisonment and fined less than one million yuan (Cao, 2016). Following this, the Qvod Corporation went into a state of neglect, losing its business opportunities and going bankrupt in 2018.

The Qvodplayer Case was the first to clarify the supervisory responsibilities of Internet platforms under users' control, but with expensive social costs and the disappearance of a leading corporation in the Internet industry. In most cases of corporate crime, results have been similar with criminal corporations being rejected by the market after sentencing and going bankrupt, resulting in unemployment and other collateral effects on society. All involved employees, investors, business partners, and stakeholders are innocent but seriously affected. Enforcement methods focused on punishment and directed by retributive justice further intensify the harms caused by crimes to the public. With so many corporate crime cases happening each year in China, many corporations have closed due to judicial enforcement, harming the public interest and economic development.

The legislative purpose of corporate criminal law must be to deter and correct the criminal behaviors of corporations, but current enforcement methods diverge from these purposes by resulting in corporation closure. Since Chinese corporate culture is shifting from non-compliance to compliance, many corporations involved in crimes for historical reasons are morally forgivable. More importantly, with the COVID-19 pandemic and complex international conditions making it more difficult for Chinese corporations (especially private-owned corporations) to survive, judicial enforcement must be reformed to be more helpful to corporations.

\section{Limited Rights Protection for Entrepreneurs: The Taizinai Case}

The pretrial enforcement process of corporate-related crime also presents deficiencies with serious harms to corporations and entrepreneurs. The investigation process adopted in China usually involves coercive measures, such as detaining directors of corporations. Even when corporations or individuals are found not guilty, the judicial process can have irreversible business consequences. The famous Taizinai Case serves as an example.

Taizinai International Group Limited, a widely known private-owned corporation, was registered by Li Chun Tu who also served as its CEO in 1996. By 2004, the corporation was China's top milk corporation, occupying $76.2 \%$ of China's market with sales reaching two billion per year and employing more than 10,000 employees. Upon seeking to go public, Taizinai's capital chain ruptured and the corporation experienced provisional liquidation in 2010. In the same year, Li Chun Tu was arrested for illegally absorbing public deposits, misappropriating funds, and duty-related misappropriation. After a 15-month detention period, Li Chun Tu was 
released without charges, but he missed important opportunities to save the corporation and protect his own interests throughout the liquidation process (Global Times, 2012).

Is it necessary to detain an entrepreneur without sufficient evidence for such a long period of time? Protecting entrepreneurs must be at the center of protecting corporations, as otherwise few will have the courage to set up businesses in China. It is often said that: "all Chinese entrepreneurs are on their way to prison". While this is an exaggeration, it warns judicial organs of the importance of protecting entrepreneurs' rights. Most entrepreneurs are of good character and cooperate well with police, and they may not have the resources to endure long periods of detention before trials. In addition, they bear responsibilities to manage corporations, which should be considered when granting bail.

Other coercive measures related to corporations may also have serious consequences. For instance, in many cases, a freezing order is placed on a corporation's property at the start of an investigation. Can a criminally suspected corporation find extra funds to support its ordinary business operations? The freezing large amounts of property will surely result in the rupturing of capital chains and force a corporation into bankruptcy even before trials. In corporate criminal cases, the adoption of coercive measures and entrepreneur's rights protection must be better regulated in China to mitigate destructive effects of the pretrial enforcement process.

\section{Poor Long-Term Effects on Compliance: The Sanlu Milk Case}

Even when corporations commit felonies that warrant their closure, the current enforcement method is ineffective at deterrence. Focusing on severe sensations of the past criminal behaviors of corporations disregards the importance of correcting common industry problems. The seeds of evil still exist in other corporations. The well-known Sanlu Baby Milk Powder Scandal illustrates this problem.

Sanlu Group Co. Ltd. was a leading private-owned corporation in the dairy products industry with more than 50 years of history. By 2008, its milk powder products had been the bestselling in mainland China for consecutive 15 years and had become a State Inspection Exemption Product. However, in 2008, it was found that the company's baby milk powder included large amounts of Melamine, a harmful chemical added to increase its protein index. The "poisoned baby milk" was found to have caused sickness in more than 39,000 babies over the past years. In 2009, the Sanlu Corporation was convicted for producing and selling fake and inferior products and fined nearly five million yuan. The company's CEO was sentenced to life imprisonment with nearly 2.5 million yuan in fines. In the same year, the Sanlu Corporation went bankrupt (Fu \& Nicoll, 2016).

Did the criminal fining and bankruptcy of a corporation solve criminal problems of the Chinese baby milk market? The answer is likely "No". The scandal is not exclusive to the single corporation. According to results released by the General Administration of Quality Supervision, Inspection and Quarantine of the PRC in 2008, 21 corporations have produced slightly "poisoned baby milk", including leading corporations, such as Inner Mongolia’s Meng Niu Dairy Group Co. Ltd. and Inner Mongolia’s Yili Industrial Group Co. Ltd. (Huang, 2018). The judicial organs only enforced criminal laws against the Sanlu Corporation while allowing other corporations to address the same problems by themselves. Some corporations recalled certain products, set up compensation procedures, and improved quality inspection practices, but others may have done far less. The enforcement of criminal law only addressed the most serious crimes and did not provide further deterrence against similar corporate crimes. As a result, over the more than 10 years following the scandal, several other cases of poor milk 
quality have emerged. Chinese consumers have not rebuilt trust in Chinese milk corporations' compliance and the country's supervisory abilities. Most parents would rather buy expensive foreign imported baby milk powder than purchase domestic brands with "safety" advertising.

Corporate crime enforcement must not be a one-off activity. The punishment of a single corporation can hardly correct the business norms of similar corporations and is ineffective at deterring future crimes. The improvement of criminal compliance costs cannot rely on the free will of corporations alone. Only if judicial organs sincerely pursue the long-term correction of corporate behaviors can business cultures meaningfully change. The judicial enforcement process currently adopted in China lacks such a mechanism.

\section{Suggestions for Corporate Crime Enforcement in China}

In 2018, judicial policy in China started to apply a reprieve approach to corporate crime, emphasizing the responsibility of judicial and administrative organs to protect corporations in their law enforcement activities (Minister of Justice of the People's Republic of China, 2018). Judicial activities have been improved by limiting the detention of entrepreneurs and preserving corporate property required for their businesses. This indicates more consideration of public interests and a shift from retributive to restorative justice in dealing with corporate crimes. However, we require further law reforms to the Criminal Procedure Law's Chinese Deferred Prosecution Agreement (DPA) system as a supplement to the traditional enforcement method, so that existing problems can be fundamentally solved. In the long run, there must be ongoing efforts to encourage corporations to set up criminal compliance programs to deter crimes more effectively.

\section{Judicial Activities: Less Detention and More Property Protection}

Driven by policies for protecting corporations, Chinese judicial organs have started to improve rights protections for entrepreneurs. On the one hand, in 2019, all procuratorates under the supervision of the Supreme People's Procuratorate (SPP) initiated a special review program on the need to detain private-owned corporations' entrepreneurs. By May 2020, 10,922 persons in custody had been examined, and 2,266 were given bail (SPP, 2020). The program indicates a call to eliminate unfavorable effects of judicial enforcement on suspected corporations. On the other hand, the SPP and Supreme People's Court (SPC) published several typical cases to guide law enforcement processes for private-owned corporations. While these cases do not entail binding authority, they are valuable in guiding improvements in judicial activities in the following three respects.

First, these cases encourage bail for entrepreneurs. For instance, in an SPP case concerning a crime where $\mathrm{Wu}$, Huang, and Liao falsely issued value-added tax special invoices, these individuals were found to be the principal and shareholders of Corporation A and the controllers of Corporation B. They knowingly received false invoices for nearly two million yuan to evade taxes for Corporation A. After being arrested, the procuratorate received applications from the employees of Corporation B to grant the three individuals bail to help the management of Corporation B run the company. After carefully reviewing the situation, the procuratorate granted bail to Huang and Liao who were deemed accessary criminals. The decision helped Corporation B return to operations (SPP, 2019a).

Second, these cases urge judicial organs to take responsibility for guaranteeing corporations' property rights. Beijing Bit Times Technology Co. Ltd.'s SPC application for compensation for illegal seizure serves as an example. The corporation was suspected of illegal business operations, but the procuratorate decided not to 
prosecute after reviewing evidence. However, in the previous investigation stage, the policy had seized all devices, money, and documents, rendering business operations impossible. The court found that the policy must compensate expenses resulting from the illegal seizures, including rents for business places, employee salaries, and all other direct losses (China Court, 2019).

Third, these cases promote the discretionary non-prosecution of minor corporate crimes. In the SPP case of Shanghai Corporation A refusing to pay labor remuneration, after arresting Liu, the controller of Shanghai Corporation A, he paid off labor debts, which exempted the corporation and himself from punishment under the Criminal Code. In this case, the procuratorate had the discretion to determine whether to prosecute or not. As the corporation had remedied damages to its victims, cooperated well with the police, and sincerely confessed, as the company has such an influence on its industry, the procuratorate decided not to prosecute (SPP, 2019b).

Overall, as judicial activities concerning rights protection in pretrail enforcement have improved in recent years, a tragedy similar to the Taizinai case might not happen again. Even though China is a civil law country that does not value the authority of precedents, more regulations are requiring judicial organs to be consistent in dealing with different cases, and the guiding cases published must be followed in most circumstances (China Court, 2020). These new rules reinforce the positive effects of these judicial programs and cases.

\section{Law Reform: Learning From the Deferred Prosecution Agreements}

Even though a reprieve approach to corporate crime has emerged, there is no sound mechanism in the Chinese criminal legal system that guarantees the protection and decriminalization of most corporations. Existing laws are very limited in eliminating the collateral consequences of corporate crimes, necessitating law reforms that introduce a deferred prosecution agreement system.

First, China's discretionary non-prosecution system is insufficient. China's criminal legal system follows the doctrine of commencement of action by law, under which the prosecutor's non-prosecution discretion is strictly restricted. According to the Criminal Procedural Law, prosecutors only have the discretion to issue a non-prosecution decision only "...Where the circumstances of the crime are slight and, in accordance with the Criminal Law, it is not necessary to give a criminal penalty or a criminal penalty may be excused...". According to a previous research, the non-prosecution rate represented only $3.69 \%$ of all cases in a province in 2016 (Zhang, Zhou, \& Chen, 2019). It could be inferred that the discretionary non-prosecution system can only be applied to a few corporate crime cases a year. Most criminal corporations are still convicted and sentenced with collateral effects on public interests. More importantly, even for corporations falling under the scope of non-prosecution, enforcement is a one-off activity without judicial supervision over whether corporations have corrected their behaviors and built a criminal compliance program. Risks of recidivism may still persist.

Second, the DPA system is valuable in solving problems. In the past decades, the United States, the United Kingdom, Canada, Singapore, and France have newly created DPA systems for corporate crime enforcement. Through this process, prosecutors have the discretion to sign a deferred prosecution agreement with the suspected corporation. The DPA grants a probation term for the corporation to fulfill obligations under the agreement, which may include paying fines, cooperating with investigations, admitting to facts and evidence, setting up or improving corporate compliance programs, complying with compliance monitors' supervision, etc. When the

\footnotetext{
${ }^{9}$ Criminal Procedure Law of the People's Republic of China, Chapter III Initiation of Public Prosecution, Article 177.
} 
term expires, if the corporation has not breached its obligations, the prosecutor ends the prosecution and the corporation is decriminalized. If the corporation fundamentally breaches obligations at any point in the term, the prosecution continues (Xiao, 2013).

Courts play different roles in this process in different countries. In the United States, before a case goes to court, parties can sign a Non-prosecution Agreement (NPA) which has same functions and leaves no role for the court. However, when a case has already been received by a court, a DPA can be signed and the court must review the prosecutor's deferred prosecution plea. However, the court review process in the U.S. is merely a formality and none of the courts reject (Bourjaily, 2015). The U.S. approach was the first to start operating in the 1990s, and other countries using similar approaches made changes upon introducing such measures to their own systems. However, the UK rejects NPAs and only accepts imported DPAs, establishing a double court review process for DPAs. Before signing a DPA, the prosecutor must propose an agreement for the court to substantially review. After signing the DPA, when the prosecutor files a plea to defer, the court reviews all details of the agreement a second time. ${ }^{10}$ The UK mode emphasizes the importance of courts much more than the U.S. mode. Other countries fall between these two modes in accepting DPAs only and granting substantial review power to courts, but with courts only reviewing once when a DPA has been signed and the prosecutor had plead to defer the prosecution.

The DPA systems developed in these countries provide procedural opportunities for criminal corporations to be decriminalized by confessing and making corrections. It helps society punish the wrongful corporations through fines stipulated in agreements while avoiding collateral consequences of formal convictions and sentences. More importantly, a DPA allows the procuratorate to constantly supervise business operations over a period of time, ensuring that corporations make fundamental changes to their structures and behaviors. The DPA's function of improving criminal compliance in an educational way backed by force can be very effective in deterring corporate crimes and addressing the hidden problems of modern corporations.

Third, the DPA system must be introduced and adjusted in China. The value of the DPA system and the need to introduce it to China has been a focus of Chinese academics, with many noted scholars writing articles calling for law reforms in this area (Chen, 2020; Li, 2020). The system complements the reprieve tendencies of Chinese corporate crime enforcement, provides more effective options for judicial organs of governing corporations, and encourages business culture transformation towards compliance. All of these advantages have been met with general support from scholars.

However, debates regarding how to adjust the system to make it more compatible with the Chinese legal system continue. One view is that we should follow the U.S. mode by placing DPAs under the sole discretion of prosecutors (Yang, 2020). China adopts a "Conditional Non-prosecution Procedure" that is very similar to the American DPA system, but it only applies to juvenile offenders committing minor crimes. Many scholars argue that the procedure should be expanded to be applicable to all corporate crimes. The other view is that there must be an independent DPA system with a substantial court review process (Tao, 2020) as the Chinese tradition of the doctrine of commencement of action by law does not allow prosecutors sole discretion over any crime. In cases of corporate decriminalization which usually challenge the public's sense of equality, courts play an arbitrary role.

\footnotetext{
${ }^{10}$ See Crime and Courts Act 2013 (UK) Schedule 17 Defered Prosecution Agreements.
} 
However, scholars agree that the UK's double review process is unnecessary and that the country should learn from other countries that use a single court review approach to the DPA system. We agree with the second view that the Chinese DPA system must be an independent procedure with a single court review process. China has a strong history of inquisitorial systems under which all judicial organs have the responsibility to punish criminals with courts taken as the most authoritative and determinative organs for justice. Under the novel corporate decriminalization procedure, court review is necessary to guarantee the credibility of decisions made to the public. In terms of judicial recourses and procedural efficiency, the mid-way mode adopted by most countries is more suited to China. The existing "Conditional Non-prosecution Procedure" can hardly fulfill the complex procedural needs of the DPA system, and thus we suggest the formation of an independent one as an additional "Special Procedure" in Part V of the Criminal Procedure Law.

\section{Ongoing Efforts: Promoting a Criminal Compliance Program}

The development of a corporate compliance program has provided judicial organs that can more effectively deter corporate-related crimes in the long term. A modern criminal compliance program usually includes: a criminal risk assessment system, training and communications, confidential reporting structures and investigation processes, incentives and disciplinary measures, and so on. ${ }^{11}$ The aim of such a program is to let corporations take more responsibility for supervising and regulating relevant individuals such as employees. This is effective in deterring crimes and saving judicial resources because such a program increases the likelihood of discovering criminal behaviors by shifting supervisory responsibilities from judiciaries to internal corporate managers who are more familiar with the norms of their employees. Since such a program increases management costs, criminal laws can play a supportive role by granting credits for lighter punishments or offering decriminalization to corporations in proceedings. First, when a corporation can prove that it has an effective criminal compliance program, it must fulfill requirements for the due diligence defense of corporate crimes in some countries. ${ }^{12}$ Second, in countries adopting a DPA system, corporations with criminal compliance programs are more likely to be considered by prosecutors in determining whether to sign a DPA (Illovsky, 2006). Third, even when corporations cannot access the former two decriminalization options, a criminal compliance program can afford them a lighter sentence based on courts' judgments. ${ }^{13}$

As mentioned above, most Chinese corporations, especially private-owned ones, have no criminal compliance program. Chinese criminal laws also offer no incentives to participate in the program. Moreover, there are no official sample criminal compliance programs or evaluation standards published by judicial organs, providing no guidance to corporations. To fundamentally change China's business environment, it is crucial to make constant efforts to shift the focus of corporate crime enforcement from postcrime punishment to the development of a criminal compliance program.

First, what a corporate criminal compliance program in China should look like must be clarified. Some Chinese administrative organs have published documents on how corporations can build administrative

\footnotetext{
11 Evaluation of Corporate Compliance Programs, U.S. Department of Justice Criminal Division (Guidance Document Updated: April 2019).

${ }_{12}$ See Bribery Act 2010 (UK) Section 7 Failure of Commercial Organisations to Prevent Bribery; Walsh, and Pyrich (1995, pp. $605,663)$.

${ }_{13}$ See United States Federal Sentencing Guidelines, Chapter 8 Sentencing of Organizations, §8C2.5. Culpability Score and $\S 8$ B2.1. Effective Compliance and Ethics Program.
} 
compliance programs, but judicial organs remain focused on criminal factors. Could the compliance program modes developed in foreign countries work well in China? What are the differences between programs against different crimes? How should judicial organs evaluate criminal compliance program effectiveness? These questions must be answered by authoritative judicial organs after conducting national-scale research and analyzing lessons learned from pilot projects. The sooner such questions are answered; the sooner business compliance culture in China can be improved.

Second, China must incentive participation in its corporate criminal compliance program. Generally, corporations with criminal compliance programs should be rewarded when they face enforcement. Developing a DPA system will be a key step in this regard. The SPP and SPC should also publish other guiding cases that clarify the role of the compliance program in the enforcement process. As discussed, the number of provisions on corporate crimes in Chinese criminal laws is very limited, making judicial practice heavily reliant on interpretation. The most efficient way to create new judicial interpretation will be to publish guiding cases where corporations with criminal compliance programs were exempted from crimes or given lighter sentences. In China, the social risks of offenders, their confessions, and how the public interest is influenced by cases are fixed factors that should be considered by judicial organs when making decisions. A criminal compliance program is naturally focused on these factors in corporate crime cases. Publishing guiding cases may be a preliminary measure, but incentivizing effects on corporations could be strong because many lack a comprehensive understanding of criminal compliance.

\section{Conclusion}

In conclusion, China's corporate crime enforcement has been improving with policies focused less on retribution and more on restoration since 2018. However, difficulties with eliminating collateral consequences and improving long-term compliance remain to be addressed by further law reforms and judicial changes. The DPA system and rules promoting criminal compliance in some countries are valuable examples for China. This article provides a brief overview of how China should borrow these tools to address criminal problems inherent to its business culture based on existing Chinese research. Specific procedures and rules to adopt fall outside the scope of this study. Corporations are expanding and becoming more powerful, complicating their criminal governance. China is not the only country that adheres to traditional corporate crime enforcement methods with negative effects on the economy and public interests. Our analysis of problems, discussion of the emerging reprieve approach, and recommendations on future changes can guide other countries in similar situations.

\section{References}

Bourjaily, G. (2015). DPA DOA: How and why congress should bar the use of deferred and non-prosecution agreements in corporate criminal prosecutions. Harvard Journal on Legislation, 52, 543-569. Retrieved from https://harvardjol.com/wp-content/uploads/sites/17/2015/10/HLL201_crop.pdf

Cao, Y. (2016). Qvod execs get prison in pornography case. China Daily. Retrieved August 1, 2020, from http://www.chinadaily.com.cn/china/2016-09/14/content_26791591.htm

Chen, L. (2018). The central issues of corporate criminal risk prevention-Based on the empirical data of unite crime in Hubei Province. Retrieved August 1, 2020, from https://www.sohu.com/a/247076120_744341

Chen, R. H. (2020). Deferred prosecution agreement system from the perspective of corporate compliance. Journal of Comparative Law, 1, 1-18. 
China Court. (2019). The application from Beijing Bit Times Technology Co. Ltd. for state compensation about illegal seizure by the police. Retrieved August 1, 2020, from https://www.chinacourt.org/article/detail/2019/12/id/4734965.shtml

China Court. (2020). The SPC issued the guiding opinions on unifying the application of laws and strengthening the search of $\begin{array}{llllll}\text { similar cases } & \text { (trial). } & \text { Retrieved } & \text { August } & 1, & \text { 2020, }\end{array}$ https://www.chinacourt.org/index.php/article/detail/2020/07/id/5375599.shtml

De Maglie, C. (2005). Models of corporate criminal liability in comparative law. Washington University Global Studies Law $\begin{array}{llll}\text { Review, } & 4(3), & \text { Retrieved } & \text { from }\end{array}$ https://openscholarship.wustl.edu/cgi/viewcontent.cgi?article=1213\&context=law_globalstudies

Diskant, E. B. (2008). Comparative corporate criminal liability: Exploring the uniquely American doctrine through comparative criminal procedure. The Yale Law Journal, 118(1), 126-176.

Fan, J., \& Li, H. (2018). Thoughts on the reform of Chinese corporate law, in commercial law (1st ed.). China: Law Press China.

Farrar, J. H. (2002). Developing corporate governance in greater china. UNSW Law Journal, 25(2), 462.

Fu, J., \& Nicoll, J. (2016). The milk scandal and corporate governance in China. Canberra Law Review, 10(3), 103.

Global Times. (2012). Who was behind charges against dairy chairman? Retrieved August 1, 2020, from $\mathrm{http}: / /$ www.globaltimes.cn/content/695865.shtml

Huang, E. (2018). Ten years after China's infant milk tragedy, parents still won't trust their babies to local formula. Retrieved $\begin{array}{llll}\text { August } & 1, & 2020, & \text { from }\end{array}$ https://qz.com/1323471/ten-years-after-chinas-melamine-laced-infant-milk-tragedy-deep-distrust-remains/

Illovsky, E. (2006). Corporate deferred prosecution agreements. Crim. Just., 21, 36-38.

Kuhn, P. A. (1984). Chinese views of social classification. In J. L. Watson (Ed.), Class and social stratification in post-revolution China (pp. 20-21). Cambridge: Cambridge University Press.

Li, H. (2013). The determination of unite's minds in unite crime. Law Science, 12, 153-160.

Li, Y. H. (2020). Criminal procedure incentives for corporation compliance in China. Journal of Comparative Law, 1, 19-30.

Lin, L. (2015). Corporate Crime in China: History and Contemporary Debates by Zhou Zhenjie, Sing. J. Legal Stud., (1), $284-287$.

Miles, L., \& Zhang, Z. (2006). Improving corporate governance in state-owned corporations in China: Which way forward? Journal of Corporate Law Studies, 6(1), 213-248.

Minister of Justice of the People's Republic of China. (2018). Opinions of the Ministry of Justice on giving full play to their functions and creating a good legal environment for the development of private enterprises. Retrieved August 1, 2020, from http://www.moj.gov.cn/news/content/2018-11/10/bnyw_42385.html

Oded, S. (2011). Deferred prosecution agreements: Prosecutorial balance in times of economic meltdown. Law Journal for Social Justice, 2, 80. Retrieved from https://jsj.files.wordpress.com/2011/08/deferred-prosecution-agreements1.pdf

Orland, L., \& Cachera, C. (1995). Corporate crime and punishment in France: Criminal responsibility of legal entities (personnes morales) under the New French Criminal Code (Nouveau Code Penal). Conn. J. Int'l L., 11, 117-120.

Parsons, S. (2003). The doctrine of identification, causation and corporate liability for manslaughter. Journal of Criminal Law, $67(1), 69-81$

Ragozino, A. (1995). Replacing the collective knowledge doctrine with a better theory for establishing corporate mens rea: The duty stratification approach. Sw. U. L. Rev., 24, 423.

Supreme People's Procuratorate (SPP). (2019a). The typical judicial protection cases related to private-owned corporations. Retrieved August 1, 2020, from https://www.spp.gov.cn/xwfbh/wsfbt/201812/t20181219_405690.shtml\#2

SPP. (2019b). The typical judicial protection cases related to private-owned corporations. Retrieved August 1, 2020, from https://www.spp.gov.cn/xwfbh/wsfbt/201812/t20181219_405690.shtml\#2

SPP. (2020). The nationwide procuratorates reviewed 10922 cases involving the necessity of detention of private entrepreneurs. Retrieved August 1, 2020, from https://www.spp.gov.cn/spp/zdgz/202005/t20200508_460633.shtml

Tao, L. X. (2020). The pre-trial diversion agreements of corporate crime in the U.S. Law and Economy, 2, 137-150.

Walsh, C. J., \& Pyrich, A. (1995). Corporate compliance programs as a defense to criminal liability: Can a corporation save its soul. Rutgers Law Review, 47, 605-663.

Wei, T. A. (1997). The research on the history of guilds system in Song dynasty. China: East Press.

Xiao, M. Y. (2013). Deferred/Non-prosecution agreements: Effective tools to combat corporate crime. Cornell Journal of Law and Public Policy, 23(1). Retrieved from https://core.ac.uk/download/pdf/216749363.pdf

Yang, F. (2020). The study on legislation about discretionary non-prosecution in corporate compliance. Criminal Science, 3 , 77-88. 
Ye, L. F. (2008). A discussion on the formation of unite crime-With a discussion on the division of liability between unite and members in the unit. China Legal Science, 6, 92-105.

Zhang, S. Z., Zhou, H. Q., \& Chen, L. (2019). The thoughts on the operation and reform of the discretionary non-prosecution system in China-From the perspectives of S Province's discretionary non-prosecution cases after the amendment of criminal procedure law. Research on Rule of Law, 1, 47.

Zhang, Y. H. (2019). The analytical report on the criminal risk of entrepreneurs (2014-2018). Journal of Henan Police College, 4, 19.

Zhang, Y. J. (2012). Corporate criminal responsibility in China: Legislations and its deficiency. Beijing Law Review, 3(3), $103-108$. 